\title{
Obesity-induced hepatic and placental inflammation are absent in obese gestating mice compared to control fed dams
}

Ingvorsen, Camilla; Thysen, Anna Hammerich; Fernandez-Twinn, Denise; Ozanne, Susan E.; Pedersen, Susanne Brix; Hellgren, Lars

Publication date:

2013

Link back to DTU Orbit

Citation $(A P A)$ :

Ingvorsen, C., Thysen, A. H., Fernandez-Twinn, D., Ozanne, S. E., Pedersen, S. B., \& Hellgren, L. (2013). Obesity-induced hepatic and placental inflammation are absent in obese gestating mice compared to control fed dams. Abstract from 15th European Congress of Endocrinology 2013, Copenhagen, Denmark.

\section{General rights}

Copyright and moral rights for the publications made accessible in the public portal are retained by the authors and/or other copyright owners and it is a condition of accessing publications that users recognise and abide by the legal requirements associated with these rights.

- Users may download and print one copy of any publication from the public portal for the purpose of private study or research.

- You may not further distribute the material or use it for any profit-making activity or commercial gain

- You may freely distribute the URL identifying the publication in the public portal 


\title{
Obesity-induced hepatic and placental inflammation are absent in obese gestating mice compared to control fed dams.
}

\author{
Camilla Ingvorsen* 1,2, Anna Hammerich Thysen1, Denise Fernandez-Twinn3, Susan E Ozanne3, Susanne \\ Brix, Lars I Hellgren1,2
}

1 Department of Systems Biology, Technical University of Denmark, 2 Centre for Fetal Programming, 3 Institute of Metabolic Science, University of Cambridge (*cain@bio.dtu.dk)

Introduction Maternal obesity is associated with increased risk of metabolic dysfunction in the offspring. It is not clear which physiological aspects of the obese state that cause this metabolic programming. Obesity causes many metabolic changes but also low grade inflammation. In this study, we have determined if increased low grade inflammation was present in obese dams compared to controls dams during gestation.

Methods Female C57BL/6 mice were fed either a standard chow diet (3\% fat) or a highly palatable obesogenic diet consisting of a high fat pellet diet ( $20 \%$ fat) supplemented with sweetened condensed milk. After 6 weeks on the diets, half the mice $(n=12)$ were sacrificed and the remaining half were mated and sacrificed on gestation day $18(n=8)$. Blood and tissues were collected for analysis.

Results The obesogenic diet increased adiposity, adipocyte size and leptin levels both in the pregestating and gestating state. There was also a tendency for increased hepatic lipid accumulation in obese mice. Body weight was increased in pre-gestating obese mice, but at the end of gestation there was no change in body weight between control and obese dams. Insulin levels were higher in pre-gestating obese dams. During gestation, a marked increase in the control dams, not seen in the obese, equalized this difference. Blood glucose levels were unaffected by diet or gestation. Local inflammation was assayed by macrophage count in liver and placenta. Hepatic macrophage count was in general reduced by gestation but only obese mice showed a significantly lower macrophage count during gestation, due to an elevated count prior to gestation. Placenta macrophage count was unaffected by the diet.

Conclusion Obese dams were found not to express increased inflammation in placenta and liver compared to lean dams, despite profound hepatic inflammation before gestation. Thus, the diet-induced inflammation is not maintained during gestation. 